\title{
Development of Interactive Learning Media on Civic Education Subjects in Elementary School
}

\author{
Reza Rachmadtullah \\ Universitas Negeri Jakarta \\ Jakarta, Indonesia \\ rezarachmadtullaheza@gmail.com
}

\author{
Nadiroh Nadiroh \\ Department of Environmental Education \\ Universitas Negeri Jakarta \\ Jakarta, Indonesia
}

\author{
Mohamad Syarif Sumantri, Zulela M S \\ Department of Elementary Education \\ Universitas Negeri Jakarta \\ Jakarta, Indonesia
}

\begin{abstract}
This study aims to develop interactive learning media on civic education learning in elementary school. This research used Research and Development method. The research procedure used Rowntree model which has three stages: planning, development, and evaluation. The instrument used in this study are questionnaires to determine the feasibility of media in terms of expert validation and field trials, and then followed by using tests to measure student learning outcomes. The preliminary study results state that the development is done in a hierarchical order. The evaluation process is carried out in three stages, the first stage of expert judgment being handled by media experts and civic education materials. The second stage was by evaluating small group of ten students. The results of the test stated that interactive learning media is feasible to use. To see the effectiveness of the developed product, the step is then followed by testing a field group of 30 students. The result of $t$-test analysis shows the difference of learning result between pre-test and posttest. Judging from the average score, it indicates that the developed media is effective in improving the learning outcomes of civic education in elementary school.
\end{abstract}

Keywords-interactive learning media; civic education; elementary school

\section{INTRODUCTION}

The learning activities of civic education in elementary school are oriented towards the forming of learners competence in accordance with psychological, intellectual, emotional and social development [1]. Civic education is oriented towards "contextual plural intelligence" A concept that open minded towards more creative, active-participatory, and meaningful and enjoyable learning needs [2]. Therefore, to facilitate the learning activities of civic education in elementary schools, it needs to be supported by appropriate learning media.

Learning media should be interesting, so it can make students interact and learn in a fun way to form a comfortable and conducive learning atmosphere; for it is necessary. Therefore, an interactive learning media is required. Interactive learning media is designed with an interesting and fun presentation pattern allowed students to understand the learning materials easier [3].

But factually, the media as one of the source of learning and has been known as a tool in the learning process are often overlooked by teachers. The absence of media in the learning process is generally due to various reasons such as limited teaching preparation time, difficulty finding appropriate media, unavailable costs and others [4].

Based on field observations and interviews conducted to teachers, in this research, it is known that the limited learning media usage during the learning process of civic education caused less focused and less active students, thus causing less optimal student learning outcomes. Based on these problems it is necessary to develop interactive learning media that can play a role in the learning process of civic education, which not only follow the development of the era but also has its own appeal to learn from it, so that students can construct their own understanding through said developed media.

Learning using interactive media is a very important, the learning media is something that can convey messages, stimulate thinking, and encourage the learning process to become easier [5]. The use of interactive learning media can motivate students to understand learning materials $[6,7,8,9]$.

Teaching using interactive media is one of the most important components in the learning process because the learning media provides convenience for teachers to deliver learning materials [10,11]. Inside the interactive media in learning, there are variations in learning and teaching activities. Some research explained this is due to how interactive media is an effort to deliver abstract learning materials to be concrete $[12,13,14,15]$. Interactive learning media has a significant influence on the interest of students to learn the competencies that are taught since interactive media can improve student learning motivation and facilitate students to easily understand the learning materials $[16,17,18]$. 
The use of interactive learning media in primary schools provides easy access to learning so that learners can develop what they understand by themselves [19].

Based on the results of problem identification and the relevant theoretical studies above, it is then decided that in this study, researchers conducted a development in interactive learning media on civic education learning in elementary school. The developed interactive media is a combination of text, images, animation using adobe flash player application, which is packed into an interactive CD form, so students can operate this media on the computer.

The purpose of this research is to develop interactive learning media on subject civic education in primary school. media developed in the validity test and tested on students to find out how big the effectiveness of media developed.

\section{METHOD}

Methods used in this study was research and development. Research conducted by creating interactive learning media using Adobe Flash Player on Civic education learning. The research procedure used was rowntree model of research procedure which has three stages: planning, development, and evaluation. The evaluation used was Tessmer's formative evaluation [20].

The subjects of this study were the students of Grade $\mathrm{V}$ of State Elementary School 01 in Mempawah district of West Kalimantan Province, Indonesia, amounted to 40 respondents, in which then divided into a Small Try-Out Group in test phase for 10 respondents, and for the tryout field trials, 30 respondents.

The data used are both qualitative data and quantitative data. Qualitative data were obtained from requirement analysis, expert material test questionnaire, expertly designed test. Meanwhile, the quantitative data is obtained from the product trial, that is the field test. The research design used was one group pre-test post-test design [21]. In this design, before the treatment students were given pre-test and after, at the end of the student's learning, a post-test were given. This design is used to determine the effectiveness of the product made.

\section{RESULT AND DISCUSSION}

Successful product developed in this research is an interactive learning media on civic education learning in elementary school, the media was designed using adobe flash player application, packed in CD form so that students can operate on their personal computer. Before designing it into an interactive media the researcher performed needs analysis to find information in developing a suitable learning media, and used it to compile the blueprint of the product in which designed in accordance to the formulated material of the subject. The materials collected came from proven sources so that interactive learning media is ready to be designed and developed.

After the interactive learning media was developed then, followed by validation by one expert material of civic education and one expert of learning media. Validation is done to obtain an assessment of interactive learning media. The results of the validation assessment by the material experts showed in the table 1:

\section{TABLE I. RESULT OF ASSESSMENT BY MATERIAL EXPERTS}

\begin{tabular}{|l|l|}
\hline \multicolumn{1}{|c|}{ Aspect } & Average \\
\hline Eligibility for content & 3,85 \\
\hline Material development & 4,00 \\
\hline Amount & 3,92 \\
\hline
\end{tabular}

The results reviewed by civic education expert on the content feasibility aspect, had an average of 3.85 which is the value of "excellent" criteria, with aspects on the material development scored 4.00 with "excellent" criteria too. So the final score of the interactive learning media value was 3.92 and can be interpreted that the development of interactive learning media on the subjects of civic education passed the assessment by material experts. Furthermore, the results of media expert validation showed in the table below:

TABLE II.

THE RESUlts OF EXPERT MEDIA ASSESSMENT OF LEARNING

\begin{tabular}{|l|l|}
\hline \multicolumn{1}{|c|}{ Aspect } & Average \\
\hline Feasibility of Content & 3,30 \\
\hline Material Accuracy & 3,60 \\
\hline Display Assessment & 4,00 \\
\hline $\begin{array}{l}\text { Language and Readability } \\
\text { Assessment }\end{array}$ & 3,80 \\
\hline Amount & 3,70 \\
\hline
\end{tabular}

The result of validation by media expert showed that the content feasibility aspect obtained an average score of 3.30, and aspects of the material accuracy earned averagely 3.60, the display interface value scored averagely 40, the language and readability assessment scored 3.80. Therefore, the final score of interactive learning media was valued at 3.92 and can be interpreted that the development of interactive learning media on the subjects of civic education passed the assessment by learning media expert

Once the media has been validated by material experts and media experts, the next step is to conduct a Small Group TryOut involving grade V elementary school students. Results from Try-Out Small Group are shown in the following table 2:

TABLE III. SMALL GROUP TRY-OUT

\begin{tabular}{|l|l|}
\hline \multicolumn{1}{|c|}{ Aspect } & Average \\
\hline Likes & 4,00 \\
\hline Understanding & 3,80 \\
\hline Book view & 3,80 \\
\hline Amount & 3,90 \\
\hline
\end{tabular}

Based on the results of small group try-out experiments, the data showed that the average results for the preference aspect or likes valued at 4.00 with "very good" criteria. On the Aspect of understanding has a value of 3.80 with "very good" criteria. In the aspect of interactive learning media display has an average value of 3.80 with the criteria of "very good". So the final score of interactive media worthiness value was 3.90, can 
be said that the development of interactive learning media on the subjects of civic education is worth using or suitable to use based on the results of small group try-out.

Final test after passing expert validation stage and small group try-out and also improvement, field try-out were conducted on 30 students, the results of this trial are presented in the table below:

TABLE IV. TRY-OUT FIELD TEST

\begin{tabular}{|l|l|}
\hline \multicolumn{1}{|c|}{ Aspect } & Average \\
\hline Likes & 3,82 \\
\hline Understanding & 3,88 \\
\hline Media view & 3,90 \\
\hline Amount & 3,86 \\
\hline
\end{tabular}

The results of field try-out test results obtained with average results for aspect like to have a value of 3.82 with the criteria of "very good", on the aspect of understanding got a value of 3.88 with the criteria of "very good", on aspects of media display earned a value of 3.90 with the criteria "very good". So the final score of interactive media worthiness valued on 3.86 and can be said that the development of interactive learning media on the subjects of civic education is worthy of use from the try-out field test results.

Field Try-out was conducted to determine the effectiveness of the developed civic education media. Effectiveness is measured by questionnaire to get students' opinions on interactive learning media on civic education learning and to analyze pre-test and post-test learning outcomes by setting a minimum score of achievement of competence of $>60$. Here is the result of post-test obtained on average score.

TABLE V. RESUlts of THE EFFECTIVENESS TEST ASSESSMENT

\begin{tabular}{|l|c|c|}
\hline & Pretest & Posttest \\
\hline Minimum value & 4,67 & 6.33 \\
\hline Maximum Value & 8.67 & 10 \\
\hline Average value & 6.93 & 8.23 \\
\hline Enhancement & 1.37 \\
\hline
\end{tabular}

At the value of pretest, there is an average value of 6.93 , after the interactive learning media usage on learning civic education average value changed to 8.23 which showed an increase of 1.37 points. The minimum pretest value of 6.93 rose to 8.23 and the maximum pretest value at 8.67 rose to 10 . This indicates a significant increase in students' ability to understand the Civic Education materials. In the test of significance by using the t-test two samples relating to Pretest and Post Test showed $\mathrm{t}$-value $=9.01$ consulted with $\mathrm{t}$-table $(\mathrm{a}=$ 0.05: 30) of 1.696 indicating that there is a significant difference between the pretest score and post-test score.

Based on the results of t-test calculations it is concluded that the interactive learning media on civic education learning has a high effectiveness since it showed a significant increase in learning outcomes. This fact is consistent with the results of Setyorini and Churiyah research [22] that suggested the use of interactive learning media in learning activities can help students improve learning outcomes, this is because the media has a function to convey the message or information learning and teaching process to attract the attention of learners.

The use of learning media for teachers and learners is very important to be used to facilitate in understanding learning about social phenomena and nature [23]. learning activities using media assistance can facilitate teachers to deliver learning materials so that the learning objectives can be achieved [24,25,26,27,28].

\section{CONCLUSION}

Based on the stages of research and development conducted in this study, the conclusion reached that the interactive learning media developed proved valid, practical and have a potential influence on student learning outcomes in civic education in elementary school. The use of interactive learning media developed can improve students' learning motivation so as to improve their learning performance.

\section{REFERENCES}

[1] Wahab, A. A. and Sapriya., Teori dan Landasan Pendidikan Kewarganegaraan [Theory and foundation of civic education]. Bandung: Alfabeta. 2011.

[2] Komalasari, K. The effect of contextual learning in civic education on students' civic skills. Educare : International Journal for Educational Studies, 4(2). 2016.

[3] Fajriah, U. N., and Churiyah, M., Utilizing Instructional Media for Teaching Infrastructure Administration. Journal of Education and Practice, 7(6), 100-111. 2016.

[4] Pujiastuti, D., Idrus, A., and Emosda, E,. Pengembangan Media Pembelajaran PKn Berbasis Multimedia Interaktif untuk SMP Kelas VIII [Development of Interactive Multimedia Interactive Civic Media for Junior High School Grade VIII]. Jurnal Tekno-pedagogi, 4(1),1-6. 2014.

[5] Ramdhani, M. A., and Muhammadiyah, H,. The Criteria of Learning Media Selection for Character Education in Higher Education. 2015.

[6] Vinod B, K., and Pathak-Shelat, M., Media literacy as a pathway to religious literacy in pluralistic democracies: Designing a critical media education pedagogy for primary school children in India. Interactions: Studies in Communication and Culture, 8(2-3), 189-209. 2017.

[7] Clark, R. C., and Mayer, R. E., E-learning and the science of instruction: Proven guidelines for consumers and designers of multimedia learning. John Wiley and Sons. 2016.

[8] Cheung, C. K., and Xu, W., Integrating Media Literacy Education into the School Curriculum in China: A Case Study of a Primary School. In Media Literacy Education in China. Springer, Singapore, 133-146. 2016.

[9] Mayer, R. E., Incorporating motivation into multimedia learning. Learning and Instruction, 29, 171-173. 2014

[10] Sumantri, M. S., and Rachmadtullah, R., The Effect of Learning Media and Self Regulation to Elementary Students' History Learning Outcome. Advanced Science Letters, 22(12), 4104-4108. 2016.

[11] Vebrianto, R., and Osman, K., The effect of multiple media instruction in improving students' science process skill and achievement. ProcediaSocial and Behavioral Sciences, 15, 346-350. 2011.

[12] Brown, A. and Sugar, W., Integrating HCI into IDT: Charting the Human Computer Interaction Competencies Necessary for Instructional Media Production Coursework.19th International Conference, HCI International 2017, Vancouver, BC, Canada, July 9-14, 2017, Proceedings (Vol. 10274). Springer. 90-86. 2017.

[13] Kristanto, A., Mustaji, M., and Mariono, A., The Development of Instructional Materials E-Learning Based On Blended Learning. International Education Studies, 10(7), 10. 2017. 
[14] Zawacki-Richter, O., Müskens, W., Krause, U., Alturki, U., and Aldraiweesh, A. Student media usage patterns and non-traditional learning in higher education. The International Review of Research in Open and Distributed Learning, 16(2). 2015.

[15] Brady, K. P., Holcomb, L. B., and Smith, B. V., The use of alternative social networking sites in higher educational settings: A case study of the e-learning benefits of Ning in education. Journal of Interactive Online Learning, 9 (2), 151-170. 2010.

[16] McDougall, J., and Potter, J., Curating media learning: Towards a porous expertise. E-Learning and Digital Media, 12(2), 199-211. 2015.

[17] McDougall J and Potamitis N., The Media Teacher's Book, 2nd edition. London: Hodder. 2010.

[18] Scarratt E and Davison D (eds)., The Media Teacher's Handbook. London: Routledge. 2011.

[19] Carol E. Craggs., Media Education In The Primary School, Newyork and London Published in the Taylor and Francis e-Library. 2002.

[20] Tessmer, M., Planning and conducting formative evaluations: Improving the quality of education and training. Psychology Press. 1993.

[21] Sugiyono, M. P. K., kualitatif dan R\&D [qualitative and R \& D]. Bandung: Alfabeta. 2008.

[22] Setyorini, D., and Churiyah, M., Increasing Activeness and Learning Outcomes by Developing Borland Delphi 7.0 Application as
Instructional Media. Journal of Education and Practice, 7(14), 129-140. 2016.

[23] Arulselvi, E., 2011. Effect of Instructional Media In The Learning Of English Grammar On The Achievement Of Teacher Training Students At Namakkal District. i-Manager's Journal on English Language Teaching, 1(3), 80.

[24] Pellas, N., Is the flipped classroom model for all? Correspondence analysis from trainee instructional media designers. Education and Information Technologies, 1-19. 2017.

[25] Dallinger, S., Jonkmann, K., Hollm, J., and Fiege, C., The effect of content and language integrated learning on students' English and history competences-Killing two birds with one stone?. Learning and Instruction, 41, 23-31. 2016.

[26] Sumantri, M. S., Strategi Pembelajaran Teori dan Praktik di Tingkat Pendidikan Dasar [Theory and Practice Learning Strategy at Basic Education Level]. Jakarta: Rajawali Pers. 2015.

[27] Arsyad, A., Media Pembelajaran [Instructional Media]. rev. ed. Jakarta: Raja Grafindo Persada. 2014.

[28] Wina Sanjaya, Perencanaan dan Desain sistem Pembelajaran [Planning and Design of Learning systems]. Jakarta : Kencana Prenada Media group. 2012. 